\title{
The Trends and Patterns of the Capital Structure and Performance of the Nigerian Banks
}

\author{
Philip Olawale Odewole, Rafiu Oyesola Salawu \\ Department of Management and Accounting, Obafemi Awolowo University, Ile-Ife, Nigeria
}

Email address:

waleodewole@gmail.com (P. O. Odewole), osalawu02@yahoo.co.uk (R. O. Salawu), rsalawu@oauife.edu.ng (R. O. Salawu)

\section{To cite this article:}

Philip Olawale Odewole, Rafiu Oyesola Salawu. The Trends and Patterns of the Capital Structure and Performance of the Nigerian Banks. International Journal of Finance and Banking Research. Vol. 2, No. 3, 2016, pp. 72-83. doi: 10.11648/j.ijfbr.20160203.13

Received: March 29, 2016; Accepted: May 10, 2016; Published: June 7, 2016

\begin{abstract}
This study analyzed the trends and patterns of capital structure and performance of financial firms in the Nigerian banking sectorwith panel data of 14 commercial banks in Nigeria over the periods 2005-2012..Descriptive methods of analysis were employed to analyze the trends and performance. The result showed that the banks exhibit $75.2 \%$ short-term financing. It shows that Nigerian banks relied heavily on external finance which is short-term in nature. Also, the result revealed that towards the end of 2008 and early 2009, the collapse of the interbank markets brought about a critical reassessment of the banksby the Central Bank of Nigeria. The study suggests that policy makers should find the means of overhauling the banking sector before its impending doom and a policy measures capable of increasing the fixed asset base of Nigerian banks.
\end{abstract}

Keywords: Trends, Patterns, Capital Structure, Descriptive Statistics, Performance

\section{Introduction}

Banks are the linchpin of the economy of any country. They are central to the country's financial systems and are essential agents in the development process of any nation. They are the cornerstones of the economy of a country. They provide the bulk of the money supply as well as the primary means of facilitating the flow of credits. The financial deregulation in Nigeria that started in 1987 and the associated financial innovations have generated an unprecedented degree of competition in the banking industry.

The decade between 1995 and 2005 was particularly traumatic for the Nigerian banking industry; with the magnitude of distress reaching an unprecedented level, thereby making it an issue of concern not only to the regulatory institutions but also to the policy analysts and the general public. The Central Bank of Nigeria introduced major reform programmes that changed the banking landscape of the country in 2004. The main thrust of the 13-point reform agenda was the prescription of minimum shareholders' funds of N25 billion for Nigerians Deposit Money Bank not later than December 31,2005. In view of the low financial base of these banks, they were encouraged to merge. Out of the 89 banks that were in operation before the reform, more than 80 percent (75) of them merged into 25 banks while 14 that could not finalize their consolidation before the expiration of the deadline were liquidated.

The Nigerian financial systems are anchored on the following economic adjustments and structurally institutional reforms which include: strengthening the institutional framework of the conduct of monetary policy, bank recapitalization or consolidation,possible elimination or reduction of government ownership of the bank, improved transparency and corporate governance; zero tolerance to misreporting and data rendition; Anti-money laundering regulations, implementation of based II principles and riskbased supervision; payments system reforms for efficiencyespecially e-payment; reforming the exchange rate management system; restructuringNigeria Security Printing and Minting Plc. Nigeria banking sector has experienced a boom cycle in the past 20-25years. After the implementation of the Structural Adjustments Program (SAP) in 1986 and the deregulation of the financial sector, new banks proliferated, mainly driven by attractive arbitrage opportunities in the foreign exchange market. Prior to the adoption of Structural Adjustment Programme (SAP), there was a limit to the capital base required of commercial banks in Nigeria. Following the adoption of SAP, the minimum capital base benchmark was increased. 
Therefore, since the 1980s, there have been further increases in the capital base, particularly coupled with the liberalization of the financial system and the introduction of Structural Adjustment Programme (SAP) in 1986.In February 1988, the capital base for commercial banks was increased to \#5 million while that of merchant banks was pegged at $\$ 3$ million. In October that same year, it was hiked to $\$ 10$ million for commercial banks and $¥ 6$ million for merchant banks. In 1989, there was further increase to $\$ 20$ million for commercial banks and $\$ 12$ million for merchant banks. In recognition of the fact that wellcapitalized bank would strengthen the banking system for effective monetary management. The regulatory authority increased the minimum paid-up capital of commercial and merchant banks in February 1990 to $\$ 50$ and $\$ 40$ millions from $\$ 20$ and $\$ 12$ million respectively. Distressed banks whose capital fell below this were expected to comply before 31st March, 1997 or face liquidation. Twenty six of such banks consisting of 13 commercial and 13 merchant banks were liquidated in January, 1998.

The minimum paid-up capital, for merchant and commercial banks was subsequently raised to uniform level of $\$ 500$ million with effect from 1st January, 1999. In 2001, when the universal banking was adopted in principle, the capital base was hiked to $\$ 1$ billion for existing banks and \#2billion for new ones. In July 2004, the Central Bank of Nigeria (CBN) announced the need for bank to increase their capital base to $\$ 25$ billion and all banks were expected to comply by December 2005. The objective of the study is to analyze the trends and patterns of capital structure and performance of financial firms in the Nigerian banking sector

The remainder of this paper is therefore arranged as follows: following the introductory session, session 2 reviews the literature. Section 3 presents the methodology of the study. Section 4 presents the analysis and discussions of result. Section 5 concludes the study and offers some crucial policy implication.

\section{Literature Review}

The literature has shown extensive interest in the relationship between Capital structure and firm performance in financial leverage. Hutchonson(1994) found that capital structure and firm performancehave a positive effect on firm return on equity provided that earnings power of the firm's assets exceed the average interest cost of debt to the firm.Toub (1995) also found significantly positive relationship between debt ratio and measures of profitability. Nerlone and Baker (1998) and Retersen and Rajan (1999) also identified positive association between debt and profitability for industries. Roden and lewellen (2001) established a positive relation between profitability buyoutfinancing packages.

There are findings from other studies however that have shown a negative relation between capital structure of a firm and its performance and therefore established that debt can have a negative effect on firm profitability. Fama and French
(1998) argued that the use of excessive debts creates agency problems among shareholders and creditors that could result in negative relationship between leverage and profitability. Allen Patt (2002) investigated how corporate governance theory predicts that leverage affects agency costs and thereby influences firm performance. They use a simultaneous equation model that accounts for reverse causality from performance to capital structure.

Huang and Song (2002) studied the leverage decisions of 799 Chinese listed companies up to the year 2000. They argue those leverage rates are generally at the low end of the spectrum typically found in developing countries. They regressed different leverage measures on a short list of explanatory variables. Akinlola, Bello and Adedipe(1983) focus on the corporate cost of capital. Adenikinju (2005) examined governance structure of Nigerian firms and their managerial characteristics and also investigates the extent to which the governance structure and managerial characteristics influence performance.

Onaolapo and Kajola (2010) examined the impact of capital structure on firm's financial performance in a nonfinancial firmusing the ordinary least square (OLS) method on thirty non-financial firms listed in Nigeria stock exchange and found thata firm's capital structure surrogated by Debt Ratio, has a significantly negative impact on the firm's financial measures.

Majunder and Chhibber (1999) found in their India study that leverage has a negative effect on performance. In supports, Gleason (2000) found a negative impact of leverage on the profitability of the firm. Hammes (2003) examined the relation between capital structure and performance by companies in Polish and Hungarian firms to a large sample of firms in industrialized countries using panel data analysis to investigate the relation between total debt performance as well as different sources of debt and found a significant negative effect for most countries. In contrary, Salawu (2007) established a positive relationship between profitability and total debt in his studies by adding that external financing has priority over internal financing.

Salman and Hendrawan (2012) examine the impact of capital structure toward performance of two groups of banks, conventional and Islamic banks in Indonesia by using profit efficiency approach. Two stages procedure were employed. In the first stage, they measure profit efficiency score for each bank in Indonesia during the year 2002-2008 by using distribution free approach (DFA). In the second stage, they employed banks standard profit function model and their performance. They discovered in the two approaches that there is a positive relationship between capital structure and performance. Iorpev, Luper and Kwanum(2012) examined the impact of capital structure on the performance of manufacturing companies in Nigeria from 2005 - 2009. Multiple regression analysis was applied on performance indicators such as return on Asset (ROA) and profit Margin (PM) as well as short-term debt to Total assets, Long term debt to total asset etc. Positive relationship was also established between leverage and profitability. 
Omorgie and Erah (2010) examine the capital structure and corporate performance of manufacturing industry in Nigerian between 1995 and 2009 using the ordinary least squares (OLS) technique of model estimation. They established a positive relationship between the firm's capital structure and its performances in the manufacturing industry.

The empirical literature also suggests a number of factors that may influence the financial structure of companies. Modigliani and Muller (1958) affirm that the capital structure does not have influence on the market value of the company which will be settled by the composition of its assets.

Modigliani and Miller (1958 \& 1963) concluded that in a frictionless world, financial leverage is unrelated to firm value but in a world with tax-deductible interest payments, firm value and capital structure are positively related. Other researchers have added imperfections such as bankruptcy cost (Baxter, 1967, Stiglitz, 1972, Krans and Litzenberger 1973). Jensen and Mechling (1976) added agency costs while (de Angdo and Masuhs 1980) added gains from leverageinduced tax shields.

Donaldson (1984) concluded from his sample companies that maximizing corporate wealth compared to shareholders' was more prevalent. He also concluded that the company survival is a function of the size of its corporate wealth. Shah and Anjah (1986) examine the financing and incorporation model for new projects by providing a theory of optimal capital structure that links risk, leverage and value and is particularly applicable to large firms. They came up with the findings that riskier firms acquire more debt, pay higher interest rates and have higher values in equilibrium.

Allen (1991) investigates the financial manager's perceptions of the determinant of listed Australian company capital structure decisions. Titman and Wesse (1998) found difficulty in the choice of explanatory variables in the analysis of cross-section variation in capital structure. Singh and Hamid (1992) and Singh (1995) who are the foremost writers and pioneers in researching into corporate capital structure in developing countries. Singh (1995) observed that developing countries firm finance themselves differently. Cobhan and Sub bramanian (1998) in their study hold a different view from Singh and Hamid (1992) result at least for India where they concluded that during the 1980s, large Indian and British firms exhibited broadly similar patterns of debt ratios.

Titman and Wese (1999) based their study of capital structure from the aspect of determinants of corporate debts ratio. Douglas and Raghuram (2000) in their studies discovered that optimal bank capital structure trades-off effects on liquidity creation cost of bank distress and the ability to force borrower repayment. Lee and Lee (2000) explain the changes in leverage and debt structure of Korean firms during the period 1981 to 1997.Dirk and Eichholtz (2001) examines the stock price reactions on announcement of both equity and debt offering by European property companies. They discovered from their study a negative price reaction on equity offering announcements which is less severe for low-tax countries and positive price reactions on the announcements of debt offerings. Booth (2001) develops a study attempting to relate the capital structure of several companies in countries with extremely different financial markets. Fattough (2001) in their study, analyses the capital structure in South Korea from 1991 through 1999.

Devic and Krstic (2001) examined the determinants of corporate capital structure in Poland and Hungary. They perform a multiple linear regression model using the samples of companies listed in Hungary and Poland. The results for Poland suggest that size is the most important determinant of corporate financing patterns. The profitability is significant only when book values of equity are used in computation of leverage. Chen (2003) examined the capital structure of firms listed on China's stock market by using an 88 firm-level panel data set from 1995 to 2000 . His findings suggested that some of the insights from modern finance theory are portable to China in that some firm-specific factors which are relevant in explaining capital structure in developed economics are also relevant in China.

Salawu, (2007, 2008, 2009) examined the factors in deciding on the appropriate amount of equity and debt in the Nigerian non-financial industry and the factors influencing firms capital structure andsuggested that credit -rating, volatility of earnings and cash flow, bankruptcy or near bankruptcy, financial distress transaction costs, fees for issuing debt and financial flexibility are the important factors in choosing appropriate amount of debt.

The two major theories in corporate finance on capital structure are Trade of Theory (TOT) and pecking order Theory (POT). While the pecking order theory of firm's capital structure and financing decisions, suggested by Donaldson in 1961 and modified by Steward Myers and Nicholas Majluf in 1984 (Frank and Goyal, 2005) states that companies prioritize their sources of finance (from international financing to equity) according to the principle of least effort or of least resistance preferring to raise equity as a financing means of last resort. Hence, internal funds are used first and hence when it is depleted, debt is issued.

This study based on Trade - of - Theory (TOT) which states that a company chooses how much debt finance and how much equity finance to use by balancing the cost and benefits. The classical version of the theory goes to Kraus and Lichtenberger who in 1973 who considers a balance between the dead-weight cost of bankruptcy and the fee+ saving benefits of debts. Trade-off Theory proposes that the optimal debt ratio is set by balancing the trade-off between the benefit and cost of debt. According to this theory, the optimal capital structure is achieved when the marginal present value of the tax shield on additional debt is equal to the marginal present value of the financial distress cost on additional debts (Bradley 1984). Myers (2001) in his own study on capital structure noted that the trade-off theory justifies moderate debt ratio. Therefore, the purpose of the trade-off theory of capital structure is to explain the strategy a firm uses to finance investments which may be equity and sometimes by debt. It predicts that a weak firm will rely exclusively on a bank for debt capital. In order words, for 
weak firms, bank debt dominates any mix of market and bank debt regardless of the priority structure.

Therefore, the static trade-off theory assumes, that firms set an optimal debt ratio and they move-gradually towards it Myers (1984). The static trade-off theory of capital structure is obtained where the net tax advantage of debt financing balances related costs. Such as financial distress and bankruptcy, holding firm's assets and investments decisions constant (Batter, 1967 ad Altman, 1984). In the view of this theory, issuing equity means moving away from the optimum and should therefore be considered bad news.

According to Myers (1984), firms adopting this theory could be regarded as setting a target debt-to-value ratio with a gradual attempt to achieve it. However, he suggested that managers will be reluctant to issue equity if they fit it is undervalued in the market. Since investors are aware of the existence of the information asymmetry they will interpret the announcement of an equity issue as a signal that the listed stocks are overvalued, which subsequently will cause a negative price reaction.

Myers et al (2001) noted that the firm would borrow up to the point where the marginal value of tax shield on additional debt is offset by the increase in the present value of possible cost of financial distress. According to Modiglian; Sc Miller (1958), the attractiveness of debt decreases with the personal tax on the interest income. A firm experiences financial distress when the firm is unable to cope with the debt holders, payment to the debt holders, the firm can even be insolvent. The theory can be explained by costs of financial distress and agency costs (Pandey, 2005).

In our literature, care has been taken to critically look at the relationship between capital structure and firm performances in developed and developing countries but over the time in the literature, no known Nigerian author has investigated the trend and pattern of the capital structure and the performance of Nigeria banks. Hence, the present study fills this gap

\section{Data and Methodology}

\subsection{Data}

The data relevant to this study were obtained from the Audited Annual Reports and Accounts of the banks for the periods 2005-2012, and these were collected from the NSE, Ibadan office and supplemented by the Fact Book, 2012.

\subsection{Model Specification}

Measures of central tendency were used in this study which is points in the scale of measurement of a distribution. The examples of such measures of central tendencies are Mean, Median, Mode, Geometric Mean, Harmonic Mean and Standard Deviation. The mean is the sum of all values in the data set divided by the numbers of values of elements in the set and it is usually symbolized by placing a bar over the symbol of the measurement averaged in the ungrouped data.

The arithmetic mean formula is shown below:

$$
X=\frac{X_{1}+X_{2}+X_{3}+\cdots+X_{n}}{N}
$$

which can be simplified by the use of the summation $\operatorname{sign} \sum$ thus:

$$
\bar{X}=\frac{\sum_{i=1}^{n} X_{i}}{N}
$$

Where $\mathrm{n}=$ number of elements in the data set and $\sum$ is a directive to the effect that we sum the variable of measurement over the sample observations from the first sample observation, $i=1$, to the last sampleelement $i=n$.

For the group data, the mean

$$
\bar{X}=\frac{\sum_{i=1}^{n} f_{i} X_{i}}{N}
$$

Where $N=\sum_{i=1}^{n} f_{i}$ is Sum of all frequencies.

The median: which is the value of the middle term of a distribution when observations are arranged in order of magnitude either ascending or descending order. It is a halfway value of a distribution as it is that value for which there are equal frequencies of greater and smaller values and given thus:

$$
\text { Median }=L+\left(\frac{\frac{N}{2}-C m}{f m}\right) C
$$

Where: $\mathrm{L}=$ Lower class boundary of the median class.

$\mathrm{N}=$ Total number of observations $\left(N=\sum_{i=1}^{n} f_{i}\right)$

$\mathrm{Cm}=$ Cumulative frequency figure corresponding to the group preceding the median class.

$\mathrm{Fm}=$ frequency of the median Class.

$\mathrm{C}=$ Width of the median Class.

The Modal value is determined by computation and not by inspection with the standard formula thus:

$$
\text { Mode }=L+\left(\frac{f_{2}}{f_{1}+f_{2}}\right) C
$$

Where $\mathrm{L}=$ Lower limit of the modal class

$\mathrm{F}_{\mathrm{i}}=$ Frequency of the class preceding the modal class.

$\mathrm{F}_{2}=$ Frequency of the class following the modalclass

$\mathrm{C}=$ Class interval.

While geometric mean (gm) with a set of data observations $\mathrm{X}_{1}, \mathrm{X}_{2}, \mathrm{X}_{3} \ldots \mathrm{X}_{\mathrm{n}}$ was defined as the $\mathrm{nth}$ root of their product thus 


$$
g m=\sqrt[n]{X_{1}, X_{2}, X_{3}, \ldots, X_{n}}=\sqrt[n]{\prod_{t=1}^{n} X_{i}}
$$

Where $\pi$ is the product sign indicating that product of the observation to be found. Taking the logarithm both sides:

$$
\log (\mathrm{gm})=\frac{\log X_{1}+\log X_{2}+\log X_{3}+\cdots+\log X_{n}}{n}=\frac{\sum_{i=1}^{n} \log X_{i}}{n}
$$

If the data is grouped such that $X_{1}, X_{2}, X_{3}, \ldots, X_{n}$ occur $f_{1}$, $\mathrm{f}_{2}, \mathrm{f}_{3} \ldots \mathrm{f}_{\mathrm{n}}$ time respectively and $\mathrm{N}$ is the total frequency. i.e. $\mathrm{N}$ $=f_{1}+f_{2}+f_{3}+\ldots+f_{n}$. Then the gm for the grouped data is defined as:

$$
g m=\left(x_{1} f_{1}, x_{2} f_{2}, x_{3} f_{3}, \ldots, x_{n} f_{n}\right)^{\frac{1}{N}}=\left(\prod_{i=1}^{n} x_{i} f_{i}\right)^{\frac{1}{N}}=\sqrt[N]{\prod_{i=1}^{n} x_{1} f_{1}}
$$

Converting to logarithm, it becomes:

$$
\log (g m)=\frac{\sum_{i=1}^{n} f_{i} \log x_{i}}{N}=\frac{\sum_{i=1}^{n} f_{i} \log x_{i}}{\sum_{i=1}^{n} f_{i}}
$$

And Harmonic mean $(\mathrm{H})$ of a values $\mathrm{X} 1, \mathrm{X} 2, \mathrm{X} 3$....Xn defined as the reciprocal of the mean thus:

$$
H=\frac{n}{\frac{1}{X_{1}}+\frac{1}{X_{2}}+\frac{1}{X_{3}}+\cdots+\frac{1}{X_{n}}}=\frac{n}{\sum_{i=1}^{n}\left(\frac{1}{X_{i}}\right)}
$$

If $X_{1}, X_{2}, X_{3} \ldots X_{n}$ have frequencies $f_{1}, f_{2}, f_{3}, \ldots, f_{n}$ respectively, then Harmonic mean is given by:

$$
H=\frac{N}{\frac{1}{f_{1} x_{1}}+\frac{1}{f_{2} x_{2}}+\frac{1}{f_{3} x_{3}}+\cdots+\frac{1}{f_{n} x_{n}}}=\frac{N}{\sum_{i=1}^{n}\left(\frac{1}{f_{1} x_{i}}\right)}
$$

Where $N=\sum_{i=1}^{n} f_{i}$

$\mathrm{Xi}=$ Value of each observation for the ungrouped data and the mid - mark of each class for grouped frequency distribution. Both Geometric and Harmonic mean were not applied to the data. Measures of dispersion, variance and standard deviation were also applied in the study and the sample variance for the data was defined as the formula below.

$$
S^{2}=\frac{\sum_{i=1}^{n} f_{i}\left(X_{i}-\bar{X}\right)^{2}}{\sum_{i=1}^{n} f_{i}-1}=\frac{\sum_{i=1}^{n} f_{i}\left(X_{i}-\bar{X}\right)^{2}}{n-1}
$$

While the Standard deviation is computed with the formula:

$$
S=\sqrt{\frac{\sum_{i=1}^{n} f_{i}\left(X_{i}-\bar{X}\right)^{2}}{\sum_{i=1}^{n} f_{i}-1}}
$$

\section{Results and Discussions}

\section{Descriptive Statistics Analysis}

Table 1 summarizes the statistics for the various explanatory variables and leverage measure for the entire sample of fourteen (14) Nigeria banks. As reflected in the Table, the pattern of capital structure of Nigerian banks exhibit $89.5 \%$ external and $10.5 \%$ internal finance. The external financing consist of $14.3 \%$ long - term debt and $75.2 \%$ short - term debt. The ratio of total debt (LEV1) on the average is $89.5 \%$ of total book value of assets. The greater percentage of the debt is of a short - term nature with a mean value of $75.2 \%$ on the average. The mean value of long term debt ratio (LEV2) is very low (14.3)\% compared to the short - term debt value of $75.2 \%$. This analysis of financial patterns reveals visible and statistically significant declining long - term leverage ratio. This suggests that banks were less able to obtain long - term debt financing. It could also be either because such financing was not available or was only available at too high cost of capital. The collapse of a sound secondary stock market may also account for this scenario deterring shareholders and long - term debt holders from investing in banking industry. The gap between the mean value of LEV2 and LEV3 reflects the underdevelopment of the long - term credit markets.

Also, over - reliance on short - term debts of a high percentage $75.2 \%$ could become a source of potential instability in the corporate sector as banks be faced with a significant shortage of financing if creditors suddenly become unwilling to roll - over the debt.From these results, it can be seen that the Nigeria banks have the profitability rate on the average of $18.9 \%$ and this profit level (PRF) is being accompanied by higher level of earnings volatility - (EVOL) of $506 \%$. Low profitability can be associated with a sharp reduction in long - term debt ratio and a high financial risk. The disparity in profitability ranges from $0.00 \%$ as minimum value to $21.00 \%$ as the maximum value. This presents a great disparity between banks in profitability and consequently reduces the credit worthiness of banks and their capacity to service debt. Also, banks with high earning volatility have a greater chance of being unable to meet their debt commitments, thereby incurring costs of financial distress.

The analysis of the assets composition reveals that fixed assets to total assets (TANG) are growing at the rate of $32.0 \%$. This indicates that the bulk of the assets of these commercial banks are held in form of current assets of $68 \%$. The implication is that the banks financed most of their developmental projects through the current assets the situation which could spell doom for the banks. The growth rate (GROW) on average is $142.2 \%$. This indicates high rate of growth prospect for the sample banks under study. This is 
evidenced by many of the branches open by the sampled banks all over the countries during the period covered by the study. This means that banks with higher growth opportunity adjust faster towards the optimal capital structure by altering the composition of newly raised funds.

The banks' size experienced high growth rate of $92.46 \%$ and low growth rate of $11.3 \%$. This may likely be as a result of effective risk management within the banks. The growth ratio of the banks size at $5.77 \%$ could not translate into more profitable results, unfortunately the growth rate size was high without a positive corresponding effect on the profit level which was put at $18.9 \%$ or $(19 \%)$ for the banks on average. This means that the high growth rate size of the banks produced a negative synergy on the profitability level for the banks.

The dividends declared was put the at highest of $196 \%$ and at the lowest rate of $10 \%$ meaning that many of the banks could not declare dividends for the periods covered by the study to their shareholders.

The standard deviation (S.D) which measures the level of variation or degree of dispersion of the variables from their mean reveals that the most volatile (Least stable) of the variables is the dividend with a standard deviation of 4.269 followed by earning volatility (EVOL) which produced a standard deviation of 2.894 and profitability 1.886 . The least volatile or most stable variable is tangibility (TANG) with a standard deviation of 0.105 followed by short - term liability with the standard deviation of 0.502 .

Table 1. Summary and Descriptive Statistics of Banks' Performance and Other Variables.

\begin{tabular}{|c|c|c|c|c|c|c|c|}
\hline & MEAN & MEDIAN & MAXIMUM & MINIMUM & STD DEVIATION & OBSERVATION & $\begin{array}{l}\text { CROSS } \\
\text { SECTION }\end{array}$ \\
\hline Total Liability/ Total Assets (Lev. 1) & 0.895 & 0.863 & 8.206 & 0.586 & 1.051 & 91 & 14 \\
\hline Long term Liability/ Total Assets (Lev. 2) & 0.143 & 0.162 & 8.206 & 0.586 & 1.051 & 91 & 14 \\
\hline Short term Liability / Total Assets (Lev. 3) & 0.752 & 0.743 & 8.291 & 0.293 & 0.502 & 91 & 14 \\
\hline Earning Volatility(EVOL) & 5.061 & 4.680 & 16.616 & 0.189 & 2.894 & 91 & 14 \\
\hline Tangibility (TANG) & 0.320 & 0.337 & 0.978 & 0.012 & 0.105 & 91 & 14 \\
\hline Size & 5.772 & 5.019 & 9.246 & 1.128 & 0.655 & 91 & 14 \\
\hline DIV & 2.242 & 1.625 & 19.694 & 0.104 & 4.269 & 91 & 14 \\
\hline Profitability(PRF) & 0.18901 & 0.12514 & 21.001 & 0.00 & 1.886 & 91 & 14 \\
\hline Growth & 1.422 & 1.220 & 19.126 & 0.0021 & 1.1201 & 91 & 14 \\
\hline
\end{tabular}

Table 2 shows that using measures of central tendency for the eight year periods (2005-2012), Zenith Bank had the highest mean capital ratio of 4.70 , followed by Stanbic bank with the mean capital ratio of 2.12 while Unity bank had the least mean capital ratio of 0.87 . Also, the median values for the banks in question follow the mean values closely in almost all the banks except Stanbic and Zenith banks indicating the presence of values that can be referred to as outliers. Moreover, the values of the standard deviation as a coefficient of variation reveal that for many of the banks, there is a fairly large variation of the sample values about the sample mean during the eight-year periods showing that there is the possibility of fluctuations.

Also, the distribution of the capital ratio for the fourteen banks analysed within the eight-year periods is nonsymmetric since there is none of the banks having skewness value of zero. In fact, for all the banks except, GTB, SKYE, UBA, UNION and WEMA Banks, the mean capital ratios exceed the median values, hence, they have positive skewness and are skewed to the right while the five banks mentioned above have negative skewness and are skewed to the left

Table 2. Summary Statistics showing the pattern and trend of the capital structure and performance of Nigeria Banks.

\begin{tabular}{|c|c|c|c|c|c|}
\hline Name of Banks & Mean & Median & Standard Deviation & Skewness & $\mathbf{N}$ \\
\hline Access & 1.16 & 1.09 & 0.37 & 0.82 & 8 \\
\hline Diamond & 1.38 & 0.87 & 1.15 & 0.62 & 8 \\
\hline FCMB & 1.28 & 1.27 & 0.12 & 0.11 & 8 \\
\hline Fidelity & 1.25 & 1.27 & 0.16 & 0.28 & 8 \\
\hline First Bank & 1.35 & 1.21 & 0.31 & 0.82 & 8 \\
\hline GTB & 1.24 & 1.29 & 0.17 & -0.77 & 8 \\
\hline Stanbic & 2.12 & 1.4 & 2.36 & 2.02 & 8 \\
\hline St. Chartered & 1.36 & 1.29 & 0.25 & 0.29 & 8 \\
\hline UBA & 1.08 & 1.08 & 0.04 & -0.25 & 8 \\
\hline Union & 1.06 & 1.17 & 0.19 & -0.52 & 8 \\
\hline Unity & 0.87 & 0.8 & 0.19 & -0.52 & 8 \\
\hline Wema & 0.92 & 1.07 & 0.35 & -0.55 & 8 \\
\hline Zenith & 4.7 & 1.16 & 8.22 & 2.01 & 8 \\
\hline
\end{tabular}

Asset tangibility is the ratio of fixed asset to the total asset. Table 3 therefore summarizesthe ratio of the Fixed Assets of the various banks to their total assets for the years under review. This reveals that Unity Bank had the highest mean value on asset tangibility of 0.17 which means that Unity Bank employed more fixed assets that could produce 
economic benefits for the foreseeable future more than other banks during the period followed by Access bank, bank, Standard Chartered and Wema bank with the asset tangibility value of 0.07 for the 3 banks that is a constant proportion of fixed asset to total assets for the period under review while First Bank Plc had the lowest mean value of $0.03 *$ between 2005 and 2012. In all the banks, the median asset tangibility value clustered around the mean value while the Standard deviation values as a coefficient of variation shows that the level of variability in the data is low. Only Diamond Bank and UBA had negative skewness with the median values exceeding the mean values on asset tangibility for the eightyear periods.

Table 3. Summary Statistics on Asset Tangibility of Nigerian banks.

\begin{tabular}{llllll}
\hline $\begin{array}{l}\text { Name of } \\
\text { Banks }\end{array}$ & Mean & Median & $\begin{array}{l}\text { Standard } \\
\text { Deviation }\end{array}$ & Skewness & N \\
\hline Access & 0.07 & 0.03 & 0.13 & 2.25 & 8 \\
Diamond & 0.04 & 0.05 & 0.01 & -0.26 & 8 \\
FCMB & 0.04 & 0.04 & 0.01 & 1.01 & 8 \\
Fidelity & 0.04 & 0.04 & 0.01 & 0.83 & 8 \\
First Bank & 0.03 & 0.03 & 0 & 0.52 & 8 \\
GTB & 0.04 & 0.04 & 0 & 0.57 & 8 \\
Skye & 0.05 & 0.05 & 0.01 & 0.03 & 8 \\
Stanbic & 0.05 & 0.04 & 0.02 & 0.55 & 8 \\
St. Chartered & 0.07 & 0.04 & 0.1 & 2.26 & 8 \\
UBA & 0.04 & 0.04 & 0.01 & -0.3 & 8 \\
Union & 0.05 & 0.04 & 0.01 & 0.19 & 8 \\
Unity & 0.17 & 0.06 & 0.33 & 2.26 & 8 \\
Wema & 0.07 & 0.06 & 0.02 & 1.12 & 8 \\
Zenith & 0.05 & 0.04 & 0.02 & 1.26 & 8 \\
\hline
\end{tabular}

Table 4. Summary Statistics on Profitability of Nigerian Banks.

\begin{tabular}{llllll}
\hline $\begin{array}{l}\text { Name of } \\
\text { Banks }\end{array}$ & Mean & Median & $\begin{array}{l}\text { Standard } \\
\text { Deviation }\end{array}$ & Skewness & N \\
\hline Access & 0.05 & 0.02 & 0.08 & 2.22 & 8 \\
Diamond & 0.02 & 0.03 & 0.01 & 0 & 8 \\
FCMB & 0.02 & 0.02 & 0.01 & -0.08 & 8 \\
Fidelity & 0.02 & 0.01 & 0.01 & 0.81 & 8 \\
First Bank & 0.02 & 0.03 & 0.01 & -0.34 & 8 \\
GTB & 0.04 & 0.04 & 0.01 & 0.82 & 8 \\
Skye & 0.02 & 0.02 & 0.01 & 0.08 & 8 \\
Stanbic & 0.03 & 0.03 & 0.02 & 1.6 & 8 \\
St. Chartered & 0.06 & 0.06 & 0.01 & -0.19 & 8 \\
UBA & 0.02 & 0.02 & 0.01 & 0.66 & 8 \\
Union & 0.05 & 0.03 & 0.03 & 1.54 & 8 \\
Unity & 0.05 & 0.04 & 0.06 & 1.74 & 8 \\
Wema & 0.1 & 0.04 & 0.18 & 2.21 & 8 \\
Zenith & 0.03 & 0.03 & 0.01 & 1.15 & 8 \\
\hline
\end{tabular}

It is clear from Table 4 that between 2005 and 2012, Wema Bank had the highest mean value on profitability with 0.10 while Diamond Bank, FCMB, Fidelity, First Bank, Skye Bank and UBA had the lowest mean profitability value of 0.02. In other words, the relative efficiency in the utilization of resources among the banks is highest with the Wema Bank than any others. The relative profitability is the lowest with the Diamond Bank, FCMB, Fidelity, First Bank, Skye \& UBA during the period. The median profitability value is close to the mean value for all the banks except at Wema Bank. There was not high variability around the sample mean for all the banks except Wema where there is the possibility of outliers during the period in question and only FCMB, First Bank and Standard Chartered had a negative skewness(profitability distribution skewed to the left of the mean value) meaning that the median profitability value exceeds the mean values for the three banks mentioned above.

From Table 5 Unity Bank had the highest mean value of 1.77 on leverage which is the ratio of total debts to total asset, followed by Access Bank (1.73) Zenith Bank (1.06) and Wema Bank (1.00) meaning that the entire aforementioned Bank's except Wema Bank had their total debt exceeding their total assets. The implication of this is that the operations of the banks are more of debts financing during the periods. Only Wema Bank had the same amount of total debt and total assets. That is, there is a uniform mix between the total debt and total assets of the bank for the period. The median values show that the middle values associate very closely with the mean with the exception of Unity and Access Banks. The Standard deviation in the Table below shows high variation both in Access Bank and Unity Bank with only Fidelity, Skye, Stanbic and Wema Banks having negative skewness since their median values are greater than the mean values.

Table 5. Summary Statistics on Leverage ratio (Total debt/Total assets) for Nigerian Banks.

\begin{tabular}{lllllll}
\hline $\begin{array}{l}\text { Name of } \\
\text { Banks }\end{array}$ & Mean & Median & $\begin{array}{l}\text { Standard } \\
\text { Deviation }\end{array}$ & Skewness & N \\
\hline Access & 1.73 & 0.82 & 2.62 & 2.27 & 8 \\
Diamond & 0.94 & 0.82 & 0.31 & 0.98 & 8 \\
FCMB & 0.79 & 0.78 & 0.07 & 0.14 & 8 \\
Fidelity & 0.77 & 0.79 & 0.1 & -0.64 & 8 \\
First Bank & 0.86 & 0.84 & 0.1 & 0.2 & 8 \\
GTB & 0.83 & 0.82 & 0.04 & 0.89 & 8 \\
Skye & 0.95 & 1 & 0.07 & -0.72 & 8 \\
Stanbic & 0.89 & 0.95 & 0.15 & -1.2 & 8 \\
St. Chartered & 0.81 & 0.79 & 0.08 & 1.42 & 8 \\
UBA & 0.89 & 0.88 & 0.03 & 0.73 & 8 \\
Union & 0.89 & 0.86 & 0.12 & 1.48 & 8 \\
Unity & 1.77 & 0.94 & 2.38 & 2.27 & 8 \\
Wema & 1 & 1 & 0 & -2.27 & 8 \\
Zenith & 1.06 & 0.97 & 0.34 & 1.7 & 8 \\
\hline
\end{tabular}

Tables 6 showed the relationship between the Long-term debt of the banks with their total assets in the relevant year of study. From this, the mean leverage ratio of Unity Bank emerged as the highest indicating that the proportion of longterm debts in the total assets is more pronounced followed by Zenith Bank, (0.27) Skye Bank (0.20) and Access Bank (0.19) while that of Stanbic Bank (-0.03) and Diamond Bank (-0.24) emerged as the lowest. The medium leverage ratio (long-term debt/total assets) showed some differences when compared to the mean values and the coefficient of variation (standard deviation) showed large variability around the sample mean for Diamond Bank, GTB, Stanbic, Union, Unity and Wema Banks. All the banks have positive skewness in their distribution of leverage ratio except Diamond, Skye, Stanbic, Union and Wema Banks where their median leverage ratios exceed the mean leverage ratio. 
Table 6. Summary Statistics on Leverage ratio (Long-term debt/Total Assets) for Nigerian Banks.

\begin{tabular}{llllll}
\hline $\begin{array}{l}\text { Name of } \\
\text { Banks }\end{array}$ & Mean & Median & $\begin{array}{l}\text { Standard } \\
\text { Deviation }\end{array}$ & Skewness & N \\
\hline Access & 0.19 & 0.2 & 0.13 & 0.02 & 8 \\
Diamond & -0.24 & 0.08 & 0.91 & -0.68 & 8 \\
FCMB & 0.1 & 0.08 & 0.09 & 2.02 & 8 \\
Fidelity & 0.05 & 0.04 & 0.04 & 0.98 & 8 \\
First Bank & 0.11 & 0.07 & 0.1 & 1.08 & 8 \\
GTB & 0.15 & 0.15 & 0.08 & 0.02 & 8 \\
Skye & 0.2 & 0.25 & 0.14 & -0.18 & 8 \\
Stanbic & -0.03 & 0.23 & 1 & -2.05 & 8 \\
St. & 0.17 & 0.14 & 0.12 & 0.22 & 8 \\
Chartered & & & & 0.46 & 8 \\
UBA & 0.04 & 0.04 & 0.02 & -0.74 & 8 \\
Union & 0.16 & 0.2 & 0.09 & 2.21 & 8 \\
Unity & 0.28 & 0.11 & 0.51 & -0.94 & 8 \\
Wema & 0 & 0.26 & 0.47 & 1.83 & 8 \\
Zenith & 0.27 & 0.16 & 0.34 & & \\
\hline
\end{tabular}

The result from this analysis reveals the ratio of short-term debts to the Total assets of the banks. From Table 7, Access Bank had the highest mean leverage ratio of 1.54 - indicating that the proportion/ of its short-term debts with the total assets employed is the highest compared with other banks during the periods, followed by Unity Bank with 1.48, Diamond Bank at 1.18 and Wema Bank at 1.00.Wema Bank maintains a constant ratio between the short term debts and total assets during the periods. Standard Chartered Bank had the least at 0.64 . The median values differ significantly for Access Bank, Diamond Bank, Unity Bank and Wema Bank between 2005 and 2012. The standard deviation values show that there is a fairly large variation about the sample mean during the eight-year periods indicating that there are fluctuations. The distribution of the ratio of total assets to short-term debts shows that half of the Banks had positive skewness (skewed to the right) while half skewed to the left (negative skewness) meaning that they are non-symmetric because none of the Banks had the mean value being equal to median value as far as leverage is concerned here in context.

Table 7. Summary Statistics on Leverage ratio (short-term debts/Total Assets) for Nigerian Banks.

\begin{tabular}{llllll}
\hline $\begin{array}{l}\text { Name of } \\
\text { Banks }\end{array}$ & Mean & Median & $\begin{array}{l}\text { Standard } \\
\text { Deviation }\end{array}$ & Skewness & N \\
\hline Access & 1.54 & 0.69 & 2.56 & 2.26 & 8 \\
Diamond & 1.18 & 0.85 & 1.07 & 1.05 & 8 \\
FCMB & 0.69 & 0.69 & 0.08 & -0.77 & 8 \\
Fidelity & 0.72 & 0.73 & 0.11 & -0.26 & 8 \\
First Bank & 0.75 & 0.76 & 0.05 & -1.12 & 8 \\
GTB & 0.68 & 0.67 & 0.08 & 0.25 & 8 \\
Skye & 0.75 & 0.75 & 0.08 & -0.11 & 8 \\
Stanbic & 0.93 & 0.62 & 1.04 & 2.03 & 8 \\
St. Chartered & 0.64 & 0.68 & 0.18 & -0.18 & 8 \\
UBA & 0.84 & 0.84 & 0.03 & 1.45 & 8 \\
Union & 0.73 & 0.74 & 0.15 & -0.03 & 8 \\
Unity & 1.48 & 0.83 & 1.88 & 2.26 & 8 \\
Wema & 1 & 0.74 & 0.47 & 0.94 & 8 \\
Zenith & 0.79 & 0.77 & 0.4 & -0.19 & 8 \\
\hline
\end{tabular}

The discussion of results on the patterns and trend of the capital structure and its performance for the banks in the financial sector in the Nigeria economy between2005-2012 is presented below. It showed an initial steady growth after the recapitalization exercise before a downturn performance in the subsequent years both inthe equity capital and debtcapital. There was an increase in the immediate post recapitalization years that resulted in the enlarged retained earnings and profit before tax for many of the banks under consideration. The equity capital for Stanbic bank was raised from initial $\$ 14,275,000$ b to $\$ 43,678,000$ b which was an increase of $206 \%$ while the debt capital stood at $\$ 5,986,000$ b as against the $\$ 4,586,000$ b translating to an increase of $30 \%$ over the initial value. This wasfollowed by an increase in both the current assets and the fixed assets which generated an increase in retained earnings of $483 \%$ over the 2005 figure and profit before tax increased by $79 \%$ between 2005 to 2006 for the bank. In 2007 Stanbic recordedan appreciable growth in both the fixed assets and current assets over the initial years. Both the retained earnings and profit after tax witnessed a positive increase from the preceding year. For the First bank Plc, the immediate recapitalization years exerted a great influence on the capital structure of the bank between 2005-2007 post-consolidation year both the retained earnings and profit before tax increased at increasing rate. Also there were increases of about $12.7 \%$ and $6.49 \%$ in both the retained earnings and profit before tax respectively. The retained earnings increased by $24.11 \%$ while the profit rose up by $37.01 \%$.

The gearing ratio for the bank was slightly improved in the early years of post-recapitalization with a value of 1:0.43 this later reduced to 1:0.42 between 2006 and 2007 signifying a slight reduction on amount payable of fixed interest charges. Current liabilities also dwindled while the total assets base increased significantly. The pattern and trend of the capital structure and performances for the most of the banks behaved almost in the same way in the immediate post recapitalization era, most of the banks recorded upsurge in equity capital. During this early period of recapitalization, there was a percentage increase of $165.68 \%$ in the equity capital of Zenith bank. In 2006, the ratio of equity capital and debt capital was put at 1:0.98 which means that the bank was more than $50 \%$ equity financed, reducing the finance risks and the amount of fixed interest charges on debt capital. This scenario imparted positively on retained earnings and profit before tax for the bank.

The assets base for UBA went up immediately after the recapitalization from the initial capital which is a percentage increase of $242 \%$ while equity capital recorded an increase of $169 \%$ over the debt capital which stood at $99 \%$ rise and the value of retained earnings and profit before tax also responded in the same direction.Riding on the back of the financial services reform, the Nigerian banking industry performed creditably between 2005-2008 post recapitalization years, dominating the financial service sector amidst intense competition. As a prelude to the second phase of consolidation in the industry, several Nigeria banks increased their access to both local and international debt and equity markets in the immediate post recapitalization years. Poised to finance big-ticket transactions in areas like oil and 
gas telecommunication, real estate, infrastructure development and the relatively untapped retails market, banking operators raised equity through public offers, right issues, private placements and global deposition receipts. In order to adequately explore emerging international traderelated business opportunity frontiers by establishing offshore subsidiaries by 2007 , the overall total assets and contingent of the Nigeria banking industry grew by $85 \%$ to \#10.5 trillion with liquid assets and loans accounting for $27 \%$ and $26 \%$ respectively for the first time in 15 years. The ratio of non-performing loans to total loans was in a single digit of $7.3 \%$ as against $10 \%$ in 2006. There was apparent loan growth and loan write- off in addition to reduction in the level of absolute non-performing loans arising from improved risk management system between $2005-2008$ post recapitalization years. Driven by growth in lending and investing activities, net earnings grew by $72 \%$ to $\$ 654$ billion in year 2008 while the industry cost-to-income ratio improved slightly to $63 \%$. Overall,profitability of the industry increased by $23 \%$.

Many factors were accounted for this pattern andtrend and stability in the banking industry during the periods prominent among them were the successful transition from one civilian government to another and the attendant confidence it has elicited from both local and foreign investors. The government's commitment to restructure some vital sectors of the economy such as agriculture, telecommunication, aviation and oil and gas sectors was also reason for the stability. Foreign exchange out- flow from the economy was low in these immediate post recapitalization periods due to low external debt commitment and favourable external reserve position. The increasing preference for nairadenominated assets over foreign ones also led to appreciation of the naira vis-a-vis other traded currencies.

However, towards the end of 2008 and early part of 2009, the global financial crisis had a devastating impact on major financial markets, undermining the solvency of firm disrupting trading liquidity and forcing a rethinking of prudential regulation. Whereas the regulatory focus had been on the soundness of individual banks, the crisis had shown the need to deal with the financial system as a whole. Challenges in the financial system and thecollapse of the interbank markets brought about a critical reassessment of the Banks by the Central Bank of Nigeria $(\mathrm{CBN})$, the Nigeria Deposit Insurance Corporation (NDIC) to ascertainthe health of all the 24 Banks then in thecountry. The Audit findings uncovered several issues, bothering on corporate Governance and mismanagementwhereby depositors fund had been used by the banks management to buy the Banks own shares, thereby aggravating the liquidity situationof the Banks. Also about $80 \%$ of the total risk assets were expired and nonperforming. These credits had very weak or no collateral to aid recovery.

Many of the banks had huge portfolio of non-performing loans which had been eithermasqueraded as contingent liability or fictitious credits passed into the accounts to make them performing. This had led to the under-provisioning by the banks, contrary to the prudential guidelines resulting in regulatory infraction for inadequate disclosure of financial information. Year 2009 was exceptionally difficult years for the Nigeria Banking system with significant reforms and shake-ups in the second half of the year. In April 2009, liquidity Ratio Requirement was reduced from $30 \%$ to $25 \%$, while Cash Reserve Requirement (CRR) was reduced to $1.0 \%$ from $2.0 \%$. the monetary policy Rate (MPC) earlier slashed to $9.75 \%$ in February 2009 was further reduced to $6 \%$ in July and remained so till the end of the year. An interest rate corridor was restored but made a symmetric, the weekly Dutch Auction system (WDAS) was reintroduced and all interbank transactions guaranteed. The retained earnings ofStanbicbank had dropped by $32 \%$ also the equity capital dropped by slightly by percentage decrease of $1.62 \%$ with a corresponding increase of $11.34 \%$ on debt capital. The implication of this was that the bank financed most of her transaction during the year with debt capital a high fixed interest charge profile. The result of this increased fixed interest charge was immediately reflected on the profit before the tax which sliced down by $32.2 \%$ reduction over the 2008 performance.

The pattern and the trend for most of the banks followed the same direction in 2009. First bank also witnessed a $6.58 \%$ reduction in her equity capital with corresponding $12 \%$ increase in debt capital and a resultant effect $79.8 \%$ reduction in profit before tax for the year while the current liability also increased by $83.6 \%$ which impaired the inability of the bank to settle her current creditors as they fell due the Zenith bank, the profit before tax dropped significantly by $35.1 \%$ while the equity value dropped by $2.98 \%$ and the debt capital increased by $41.57 \%$ in 2009 . The profit before tax for FCMB in 2009 sliced by $47.26 \%$ while the current liability increased by $7.36 \%$ over a reduction in current assets which declined by $9.9 \%$ while the equity capital dropped by $3.0 \%$. The year 2009signaled a negative synergy for most banks in the industry.

The CBN conducted a special audit and stress test on all 24 banks operating in Nigeria and declared 10 of them as being in grave conditions for having liquidity, capital adequacy and corporate governance challenges. This led to the injection of $\$ 620$ billions as intervention capital to support the banks and the removal of eight banks management team. As a result of the banking industry challenges and falling oil revenues, Standard and Poor's reduced Nigeria's sovereign credit rating from BB-to $\mathrm{B}+$ in August 2009. The second half of the year 2009 was more breathtaking for investors and analysts as the regulatory authority indicated that local banks were burdened with poor risk assets in certain business areas which resulted in decline in equity prices as debtors sold to repay loans andbanks resorted to minimizing their exposure to certain sectors of the economy. Most banks slowed down lending for fear of accelerated loan default while some banks placed greater emphasis on deposit mobilization and treasury activities escalated. An estimated $\$ 2$.2trillion worth of bad loans in the sector was sold to State owned Assets Management Corporate Nigeria (AMCON). 
In 2010, in an attempt to increase liquidity in the system, government released $\$ 500$ billion intervention fund consisting of $\mathrm{a} \# 200 \mathrm{~b}$ refinancing facility for small and medium scale enterprise (SMES) and $\$ 300$ billion for the power and aviationsectors.Also AMCON acquired all capital market related loan (margin and share backed loans) in the industry and issued up to $\$ 3$ trillion bounds to finance the acquisition of non-performing assets in the banking sector.

As part of the mechanism for resolution, the CBN with the support of the Federal Ministry of Finance proposed the creation of the Assets management corporation of Nigeria (AMCON). The specific mandate of AMCON is to "purchase a significant portion of the non-performing assets in the Nigeria banking sector and assist in recapitalizing under capitalized banks to help restore the health of the banking sector. For Wema bank, its performance in the period under review was driven largely by loan recovery. A significant portion of the profit is accounted for by write-backs to the profit and loss account for recovered loans. The banks gross earnings for the 12-month period of 2010 was $\$ 19.93$ billion compared to a grossearnings of $\$ 16.27$ billion for the 9month period to December 2009. The retained earnings was $\$ 32.19 \mathrm{~m}$ compared to year 2009 retained earnings of $\$ 30.40 \mathrm{~m}$.

Year 2010 witnessed an increase in the total assets base on most banks.For the UBA, the total assets rose by $5 \%$ while gross loans and advance to customer were flat at $\$ 674 \mathrm{~b}$ as against $\$ 680$ bn in 2009 . The bank liquidity ratio was strong at $39 \%$-which was $9 \%$ abovethe regulatory minimum. Customers'deposits as at $31^{\text {st }}$ December, 2010 closed at $\$ 1.27$ tr as against $\$ 1.25$ tr in 2009 . The loan to deposit ratio stood at $49.6 \%$ as against $51 \%$ in 2009 indicating a strong elbow room to grow loan which was well below peer average of $70 \%$. The shareholder funds stood at $\$ 179 \mathrm{bn}$ as against $\$ 186$ bn in 2009 , culminating in a risk weighted capital adequacy ratio of $18 \%$ which was in excess of the regulatory threshold of $10 \%$.

The First Bank Group gross earnings when compared to annualized figure for 2009 declined by $11 \%$ from $\$ 194 \mathrm{~b}$ recorded in the nine month to December 2009, to $\$ 231$ b in the 12 months to December 2010. Relative to cash year the bank group profit before tax movedfrom $\$ 13.36 \%$ in 2009 to $\$ 43.2 \mathrm{~b}$ in 2010 after charging the $1 \%$ general loan loss provision of $\$ 11$.4billion in thereview period. After tax, group profit rose by $411 \%$ from $\$ 4.9$ billion in the nine months to December 2010. The banks profit rose by $148 \%$ to $\$ 26.9$ billion, from $\$ 1.2$ billion over the same period. Red flags were raised in the review period as declining yields on loan books drove significant decline in interest income. The effect of lower yields and rising cost showed up in worsening cost-to -income ratio which deteriorated from $59.2 \%$ to $65.5 \%$. The Bank achieved adequacy ratio of $27.57 \%$ in the period under review well in excess of the regulatory minimum of $10 \%$, this pattern and trend continued for most of the banks in the sector for the current years 2011-2012 under review.

\section{Conclusion and Policy Recommendation}

The objective of this paper is to analyze the trends and patterns of the capital structure and the performance of Nigeria banks. The Nigerian banking industry's performance during 2005-2008 post -re capitalization years witnessed an impressive outing,dominating the financial service sector amidst intense competition with high profits and returns.However,towards the tail end of 2008 and early part of 2009, the challenges, in the financial system and the collapse of the interbank markets brought about a critical re-assessment of the Banks by the Central Bank of Nigerian(CBN),the Nigerian Deposit Insurance Corporation(NDIC) to ascertain the health of all the 24 banks then in the country coupled with a global financial crisis that had a devastating impact on major financial markets,undermining the solvency of firms,disrupting trading liquidity and forcing a rethinking of prudential regulation.Many of the banks had huge portfolio of non-performing loans which had been either masqueraded as contingent liability or fictitious credits passed into the accounts to make them performing.The decline intheir profitability led directly to a decrease in earnings per share and dividends during the periods. Many would not even declare dividends for long periods of time.The information made public for the investors was onselectivebasis and misleading which made sound informed decisions impossible for the investors on the quality of bank earnings, the strength of their balance sheet and the risks of their business.

It is therefore possible that some banks engaged in manipulating their books by colluding with other banks to artificially enhance financial position and therefore, practices such as converting non-performing loans into commercial papers and bank acceptance and setting up off statement of financial position to guide losses were the order of the days for some of these banks.

There is a great need for policy measures capable of increasing the fixed asset base of Nigerian banks. The policy makers should find the means of overhauling the banking sector before its impending doom. More aggressive pragmatic changes and reforms are needed in the Nigerian banking industry.

\section{References}

[1] Abor, J. (2005), "The effect of Capital Structure on Profitability: an empirical analysis of listed firms in Ghana”,Journal of Risk Finance, 6(5): 438-445.

[2] Abor, J. (2007), "Debt Policy and Performance of SMEs,"Journal of Risk Finance, 8(4): 364-379.

[3] Adeyemi, S. B., and Oboh, C. S. (2011)."Perceived Relationship between Corporate Capital Structure and Firm Value in Nigeria".International Journal of Business and Social Science, 2(1):19-32

[4] Berian, andDanbolt, (2001), "Capital Structure and its Determinants in the United Kingdom: ADecompositionalAnalysis", Applied Financial Economics, 2(1):32-42 
[5] Brounen, D., and Eichholtz, P.M.A. (2001), "Capital Structure Theory: Evidence from EuropeanProperty Companies Capital offerings", Forthcoming in Real Estate Economics, 21(4): 201-305

[6] Chen, J.J. (2003), “Determinants of Capital Structure of Chinese Listed Companies", Journal of Business Research, 1(2):42-58.

[7] Chen, C.J.P., Cheng, C.S.A., He, J and Kim. J. (1997), “An Investigation of the Relationship between International Activities and Capital Structure", Journal of International Business Studi, (Third Quarter), 2(1):563-577.

[8] Donald, G. (1961), “Corporate debt Capacity: A study of corporate debt Policy anddetermination of Corporate debt Capacity", Boston: Division of Research, Havard School ofBusiness Administration, 5(6):206-225

[9] Drouglas, W. D., Rajan, R.J. (2000), A theory of Bank capitalJournal of Finance, 55(6):20-56

[10] Eisenchardt, K.M. (1989), Agency theory: An assessment and review. The academy of management Review, 14(2): 57-74.

[11] Fama, E. F. (1980), "Agency Problem and the Theory of the Firm”, Journal of Political Economy,88(2):288-307.

[12] Fama, E.F. (1981), "Stock Returns, Real Activity, Inflation and Money", American EconomicReview, 71(2):545-565.

[13] Fama, E.F.and French, K.R. (2002), “Testing Trade-off and Pecking order Predictions aboutDividends Debts, Review of Financial Studies, 15(2): 133-139.

[14] Fama, E.F. and Jensen, M.C (1983), "Separation of Ownership and Control" Journal of Law and Economics, 26(1): 301-325.

[15] Frank, M.Z. andGoyal, V.K.(2003), "Trade-off and Pecking Order Theories of Debt", Journal of Financial Economics, 8(1): 217-248.

[16] Green, C. J., Murinde, V. and Suppakitjarak, J. (2003), "Corporate Financial Structure in India".South Asian Economic Journal, 4(2):245-274.

[17] Gropp, R.,Heider,F. (2008), "The determinants of capital structure. Some evidence from banks" Centre of European Economic Research, 2(1):305-375.

[18] Gropp, R., and Heider, F. (2010), "The determinants of Bank Capital Structure”, Review of Finance 14(1): 587:62.

[19] Howe, S.S. and Shilling, J.D. (1988), "Capital Structure Theory and REIT Security Offerings". Journal of Finance, 43(2): 983-993.

[20] IorPev, L. and Kwanum, I.M. (2012), "Capital structure and Firm Performance: Evidence from manufacturing companies in Nigeria", International Journal of Business and Management Tomorrow.2(5):205-221

[21] Jensen, M. (1986), "Agency Costs of free cash flow, Corporate Finance and takeovers". American Economic Review. 76(2):55-81.

[22] Jensen, M.C. and Meckling, W.H.(1976), "Theory of the Firm: Managerial Behaviour, Agency Costs and Ownership Structure", Journal of Financial Economics, 3(2): 303-360.

[23] Jensen, M,; Solberg, D. andZorn, T. (1992), "Simultaneous
Determinants of insider Ownership, Debt and Dividend Policies", Journal of Financial and Quantitative Analysis,27(3): 247-261.

[24] Kester, V. (1986), "Capital and Ownership Structure: A Comparison of United States and Japanese Manufacturing Corporations" Financial Managements,2(1):5-16.

[25] Kraus A., and Litzenberge R.H., (1973), "A State Preference Model of Optimal FinancialLeverage",Journal of Finance, 7(2): 911-922.

[26] Lee, Jong - Wha, Lee, Y.S and Lee, Byung - Sun (2000), $\mathrm{s}$ "The Determination of CorporateDebt in Korea", Asian Economic Journal,14(4):5-17.

[27] Lewis, P., Stein, H. (1997), "Shifting Fortunes: The Policies Economy of FinancialLiberalization in Nigeria", World Development, 25(2): 5-22.

[28] Margarits, D., Psillaki, M. (2007), "Capital Structure and firm efficiency", Journal of Business Fiancé and Accounting,34(2): 1447-1469.

[29] Miller, M.H. (1977), "Debt and Taxes”, Journal of Finance, 32(2): 297-355.

[30] Modigliani, F.and Miller, M.H. (1958), "The cost of capital, Corporate Finance and the theory of investment", American Economic review, 48(3):261-297.

[31] Myers, S. (1984), "The Capital structure puzzle", Journal of Finance, 39(2):575-592.

[32] Myers, S.C. (2007), "Determinant of Corporate borrowing", Journal of financial Economics, 2(1):147-175.

[33] Myers, S.C., Majluf, N. (1984), "Corporate Financing and Investment decisions when firms have information investors do not have", Journal of financial Economics, 39(2): 575-592.

[34] Nengiju J., Robert P., Allen, M. P., and Weisbach, M.S. (2005), Journal of Financial and Quantitative Analysis, 2(2):485-521.

[35] Olowe, R.A. (2009), "Financial Management Cponcepts Analysis and Capital", Lagos, Pp. 38-60.

[36] Vasa,O. A., and Ose, A. D. (2010), "Capital Structure and Corporate performance in Nigeria: An empirical Investigation", $A A U J M S, 1(2):$ 10-38.

[37] Onaolapo, A. A. and Kajola, S. O. (2010), "Capital Structure and firm Performance: Evidence from Nigeria", European Journal of Economics, Finance and Administrative Science,1(2):35-87.

[38] Oswald, B. (2006), "Guide to Financial Analysis. New York: Mcgraw Hill Publications",2(2): 36- 37.

[39] Pandey, I.M. (2004), "Capital Structure, Profitability and Market Structure: Evidence from Malaysia", Asia Pacific Journal of Economics and Business, 8(1):12-15.

[40] Rongbing H. J., Ritter, J. R. (2009), "Testing Theories of Capital structure and Estimating the speed of Adjustment", Journal of financial and Quantitative Analysis, 44(2):2-10.

[41] Salawu, R.O. (2007), "The determinants of the capital structure of Financial firms in Nigeria: The Financial Managers' Perspectives", The Global Journal of Business Research, 1(1): 60-68. 
[42] Salawu, R.O., and Agboola, A.A. (2008), "The determinants of capital structure of large non-financial listed firms in Nigeria" The International Journal of Business and Finance Research, 2(2):75-84.

[43] Salman S. A. and Anjan V. T. (1987), "Optimal Capital Structure and Project Financing" Journal of Economic Theory, 42(2): 209-235

[44] Shirai, S. (2002), "Have Ladias Financial Market Reforms change Firm's Corporate Financing Pattern?" Research Paper Series, NO38, ADB Institute.
[45] Titman, S., and Wessels, R. (1988), "The Determinants of Capital Structure Choice", Journal of Finance, 43(2): 1-19.

[46] Van Home, J. C. (2007), "Financial Management and Policy. $4^{\text {th }}$ Ed. Englewood Cliffs: Prentice Hall”, 5(2): 672-688.

[47] Walter, J.E. (2009), "A Discriminant Function for earnings Price ratios of Large Industrial Corporations", Review of economics and statistics, 41(2):44-52. 